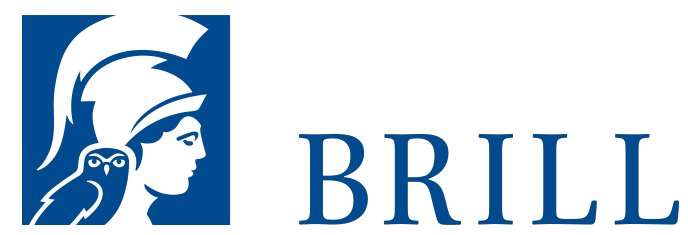

\title{
How to do things with Nietzsche
}

Nietzsche als Methode - Eine Versuchanordnung mit drei Opern Richard Wagners

Author:Jürgen Hofbauer

Was wäre, wenn das Feld der Nietzsche-Interpretation, bis hin zu Heidegger und über ihn hin-aus, sich alleine deshalb in so hitziger Diskussionsaufregung befand, weil in ihm eine entscheidende Stelle unbelichtet blieb? Gibt es einen blinden oder gar - sprachphilosophisch betrachtet - „stummen Fleck“, der das Interpretationsvermögen gefährlich trübt? Ist das antithetische Ringen der unterschied-lichsten Vereinnahmungen nur das Ergebnis einer versäumten Befragung der Praxis des Interpretierens auf ihre grundsätzliche Tauglichkeit? Wenn ja, müsste ein Gros der bisherigen Nietzsche-Auslegungen radikal in Frage gestellt werden. - Jürgen Hof-bauer versucht dies zu zeigen und entwickelt eine Nietzsche-Interpretation, die sich loslöst von den großen Schlagworten (Ü-bermensch, Wille zur Macht, Ewige Wiederkehr...) des Diskur-ses. Nicht was Nietzsche gesagt hat rückt in den Vordergrund, sondern die jedes Fundament zersetzenden Denkbewegungen, die zuletzt „Nietzsche als Metho-de“ verständlich machen sollen. Exemplifiziert wird das in einer Versuchsanordnung mit drei zentralen Werken Richard Wag-ners: Tannhäuser, Siegfried und

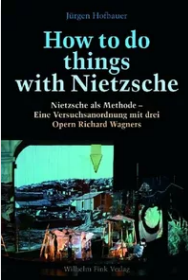

Pages: 192 Seiten

Language:

German

Subjects:

German

Idealism, Philosophy

Publisher: Brill | Fink

Paperback Publication date: O5 Oct 2007 ISBN: 978-37705-4417-2 List price USD $\$ 28.00$ Tristan. 
For more information see brill.com

Order information: Order online at brill.com +44330 333 0049 | customerservices@brill.com Submission information: brill.com/authors

Titles published by Brill | Fink, Brill | mentis or Brill | Schöningh: +49(o)715413279216| brill@brocom.de 